\title{
NFKBIZ wt Allele
}

National Cancer Institute

\section{Source}

National Cancer Institute. NFKBIZ wt Allele. NCI Thesaurus. Code C150026.

Human NFKBIZ wild-type allele is located in the vicinity of 3q12.3 and is approximately 33 $\mathrm{kb}$ in length. This allele, which encodes NF-kappa-B inhibitor zeta protein, is involved in the modulation of nuclear factor kappa-B-mediated gene transcription. 